\title{
METHICILLIN-RESISTANT STAPHYLOCOCCUS PSEUDINTERMEDIUS, A NEW THREAT IN HUMAN AND VETERINARY MEDICINE?
}

\author{
Maja Velhner ${ }^{1^{*}}$, Ljubica Bratić ${ }^{2}$, Sara Savićl, Dalibor \\ Todorović ${ }^{1}$, Bojana Prunić ${ }^{1}$, Dubravka Milanov ${ }^{1}$ \\ ${ }^{1}$ Scientific Veterinary Institute "Novi Sad”, Novi Sad, Republic of Serbia \\ ${ }^{2}$ Department of Biology and Ecology, Faculty of Sciences, \\ University of Novi Sad, Republic of Serbia
}

\section{Abstract}

In this paper we briefly described the worldwide distribution of methicillin-resistant Staphylococcus pseudintermedius (MRSP) in dogs and cats. The most common sequence type of MRSP strains in dogs is ST71 as it was detected in isolates on four continents (Europe, Asia, North and South America). However, several different MRSP sequence types are detected in small animals, and the presence of new genetic variants is continually reported. Sometimes isolates belonging to the same sequence type (ST) are detected in dogs, cats, their owners, and veterinarians. MRSP is often multidrug-resistant and its resistance patterns are usually linked to certain sequence types. The resistance to non-beta-lactam antibiotics such as erythromycin, clindamycin, tetracycline, gentamicin, enrofloxacin and sulfamethoxazole/trimethoprim is also recorded. Taking into account that MRSP tends to confer multidrug-resistant phenotype, it is quite challenging for veterinarians to give adequate therapy in clinically ill animals. It would seem as if the significance of MRSP in the clinical epidemiology of humans is not firmly established. However, the importance of MRSP in human medicine should not be underestimated given the fact that all methicillinresistant Staphylococcus spp. carry resistance and virulence genes and have the potential to share their genetic elements with other bacteria.

Key words: antimicrobial resistance, cats, dogs, humans, MRSP, Staphylococcus pseudintermedius.

\footnotetext{
${ }^{1^{*}}$ Corresponding author: maja@niv.ns.ac.rs
} 


\title{
METICILIN REZISTENTNI STAPHYLOCOCCUS PSEUDINTERMEDIUS, NOVA PRETNJA ZDRAVLJU LJUDI I ŽIVOTINJA?
}

\author{
Maja Velhner ${ }^{*}$, Ljubica Bratić ${ }^{2}$, Sara Savić ${ }^{1}$, Dalibor \\ Todorović ${ }^{1}$, Bojana Prunić ${ }^{1}$, Dubravka Milanov ${ }^{1}$
}

${ }^{1}$ Naučni institut za veterinarstvo "Novi Sad”, Novi Sad, Republika Srbija

${ }^{2}$ Departman za Biologiju i Ekologiju, Prirodno matematički fakultet, Univerzitet u Novom Sadu, Republika Srbija

\section{Kratak sadržaj}

U radu prikazujemo relevantne činjenice o meticilin rezistentnim sojevima Staphylococcus pseudintermedius (MRSP) koji su široko rasprostranjeni u populaciji pasa i mačaka širom sveta. Metodom sekvenciranja genoma, kod izolata poreklom od pasa na teritoriji Evrope, Azije, Severne i Južne Amerike, najčešće je ustanovljen genetički tip ST71. Međutim, kod MRSP poreklom od malih životinja utvrđeno je više različitih genetičkih varijanti, a kontinuirano se izveštava o nalazu novih. Ponekada se isti genetički tip MRSP može naći kod pasa ili mačaka, njihovih vlasnika i veterinara. Izolati Staphylococcus pseudintermedius često poseduju rezistenciju na više klasa antibiotika, pri čemu je tip rezistencije u korelaciji sa određenim genotipom. Meticilin rezistentni sojevi Staphylococcus pseudintermedius takođe mogu biti rezistentni i na antibiotike koji ne pripadaju grupi beta-laktama, kao što su eritromicin, klindamicin, tetraciklin, gentamicin i trimetoprim/ sulfametoksazol. Zbog toga terapija infekcija pasa i mačaka koje su izazvane sa MRSP, može predstavljati veliki izazov u veterinarskoj kliničkoj praksi. Iako meticilin rezistentni sojevi Staphylococcus pseudintermedius nisu od posebnog značaja u humanoj medicini, ne treba podceniti njihovu ulogu $\mathrm{u}$ potencijalnom transferu gena virulencije i gena rezistencije na druge srodne ili nesrodne vrste bakterija.

Ključne reči: rezistencija na antibiotike, mačke, psi, ljudi, MRSP, Staphylococcus pseudintermedius

\section{INTRODUCTION}

Shortly after methicillin was introduced into medical practice, the resistance to this antibiotic occurred in Staphylococcus aureus isolates. Not only did 
MRSA become one of the most important nosocomial pathogens worldwide, but it was also a significant community-acquired and livestock-associated pathogen (Gordon and Lowy, 2008).

The resistance to methicillin occurs due to the presence of mecA gene that encodes penicillin-binding proteins (PBPs). This gene is integrated into a staphylococcal cassette chromosome mec (SCCmec) locus. The integration of the cassette is accomplished by the recombinase encoded by $c c r$ gene. The sequence of $m e c-s c c$ is used for the determination of SCCmec cassette type and the establishment of its epidemiological status (Gordon and Lowy, 2008, rev. Velhner et al., 2016). Other additional methods of MRSA molecular typing include spa typing, multilocus sequence typing (MLST) and pulsed-field gel electrophoresis (PFGE). Isolates causing nosocomial infections health careassociated MRSA (HA-MRSA) belong to SCCmec types I, II or III and less frequently to types IV and V, while community-acquired MRSA (CA-MRSA) belongs to SCCmec types V and VI (Kasai et al., 2016, rev. Velhner et al., 2016,).

Staphylococcus pseudintermedius has been recognized as a relatively new species since 2005 when it was isolated from a dog, a cat, a horse and a parrot by Devriese et al. (2005). Methicillin-resistant Staphylococcus pseudintermedius (MRSP) was first reported in Europe in 2006 and the whole genome sequence was available by 2013 (Moodley et al., 2013). MRSP belongs to Staphylococcus intermedius group and causes opportunistic infections in dogs and cats. There are six coagulase-positive staphylococcus species including S. aureus, S. intermedius, S. schleiferi subsp. coagulans, S. hyicus, S. lutrae, S. delphini and S. pseudintermedius. Among them, S. intermedius, S. pseudintermedius and S. delphini are very closely related (Sasaki et al., 2007).

MRSP produces coagulase the same as MRSA strains, and therefore laboratory identification can be a bit challenging (Sewid et al., 2018). However, molecular phylogenetic analysis (Sasaki et al., 2007), multiplex PCR (Sasaki et al., 2010) and MALDI-TOF MS diagnostic (Nisa et al., 2018) are overcoming difficulties of their phenotypic identification.

Staphylococcus pseudintermedius is often a part of normal flora in healthy dogs (Kjellman et al., 2015). However, it can cause skin infections, pyoderma, otitis externa and urinary tract infections in dogs and can be isolated from postsurgical sites of infection (Duijkeren et al., 2011, Somayja et al., 2016). Apart from dogs, MRSP can also be isolated from cats, less frequently from horses and humans (Devriese et al. 2005, Kadlec et al., 2010, Dos Santos et al., 2016). Even though it is sometimes a part of normal genital flora of bitches, $S$. pseudintermedius can cause reproductive problems leading to neonatal mortality (Ruzauskas et al., 2016, Corro et al., 2018). 
In this brief review we described the worldwide distribution of MRSP specific sequence types, their antimicrobial resistance and the significance of MRSP in clinical epidemiology of humans and small animals, mainly dogs and cats.

\section{SEQUENCE TYPE DISTRIBUTION OF THE MRSP}

All MRSP isolates from dogs described until 2016 belong to 16 different sequence types and the most frequent clone worldwide is ST71. This clone was detected on four continents (Europe, Asia, North and South America). The most prevalent clone in the USA is ST68, while in Asia it is ST45/ST112. Other clones that are less abundant belong to sequence types ST45, ST258, ST261, ST112, ST265, ST68, ST169 and ST181. Interestingly, the genetic diversity among methicillin-sensitive Staphylococcus pseudintermedius (MSSP) is higher compared to MRSP and seven STs are present in both groups of isolates (Perreten et al., 2010, dos Santos et al., 2016). Clonal complex (CC) 71 is detected only in MRSP, while CC75 is exclusively found in MSSP strains. In addition, various SCCmec types were found in MRSP clonal lineages due to their independent acquisition (dos Santos et al., 2016). All MRSP isolates collected from felines in different European countries belonged to ST71, spa type 02 and SCCmec type II-III. A single MRSP isolate from Canada harbored SCCmec type V element (Kadlec et al., 2010). A research work carried out in Iran showed that MRSP can be isolated from the nostrils and perianal area of healthy dogs and cats and those isolates carried the cassette chromosome SSCmec II and V (that have been detected in two and 10 isolates respectively) (Tabatabaei et al., 2019).

It was established that the presence of MRSP-ST71 is slowly decreasing in dogs with skin and soft tissue infections in France (Bergot et al., 2018). Even though this trend was not statistically significant in the 2012-2013 period, the expanding decreasing trend was reported in the following years (2015-2016). The majority of MRSP isolates have their specific genetic background, except for a few clones such as 258. Also, of great importance is an emerging ST496 clone in France, previously identified in Australia, primarily in Sidney. In Finland, the examination of 1958 clinical isolates of Staphylococcus pseudintermedius showed that 266 isolates were oxacillin-resistant and 321 multidrugresistant. The total number of 42 different sequence types was identified and among those 19 STs were new in a database. MRSP was predominantly diagnosed in private clinics in Finland since more patients with dermatological problems were admitted there compared to the Veterinary teaching hospital 
(Grönthal et al., 2017). The collection of MRSP isolates from dogs (No 28) and cats (No 11) from Thailand was studied thoroughly in order to identify resistance genes, spa and dru types, MLST and PFGE. The most frequent MLST among the same PFGE cluster was ST45 followed by ST112, ST155, ST282, including three novel MLST types ST432, ST433 and ST434. The ST45, previously identified in Thailand, was found in 30 isolates that belong to the two most common PFGE patterns (Kadlec et al., 2016). In a research work from Japan (Kasai et al., 2016), clear differences were found between HA-MRSP and CA-MRSP isolates from dogs. The most homogenous group of isolates was SCCmec type III and most of them belong to the pulsotype A. Additionally, they have similar resistotypes and belong to the endemic clone ST71. SCCmec type $\mathrm{V}$ isolates were heterogeneous as they were classified into 25 pulsotypes. Furthermore, there were differences between MRSP and MSSP strains since MRSP was usually identified in older dogs after hospital admission. A survey conducted in a small animal hospital in Germany also contributed to the identification of SCCmec type II-III strains among MRSP isolates (60 out of 814 dogs included in the study were MRSP positive). MRSP identification has proved significant in dogs hospitalized and treated with antibiotics within six months before sampling. Samples had been collected before they entered the clinic. All isolates conferred high resistance rates to antibiotics (Nienhoff et al., 2011). A research carried out in Italy at the University of Bari revealed that out of 175 clinical samples from dogs, 151 were culture positive and 63 were identified as $S$. pseudintermedius by PCR detection of nuc gene. The most dominant clone was ST71, identified in 48\% isolates. Single-locus variants of ST71 were ST410 (found in four isolates) and ST261 (two isolates), while one isolate was identified as a double-locus variant ST290. The new allelic profile, unrelated to ST71, was detected in one isolate and assigned as ST477. The SCCmec type II-III was identified in $67 \%$ isolates, while $33 \%$ isolates, including ST258, were SCCmec type IV (Ventrella et al., 2017). Three different sequence types ST71, ST252 and ST305 were identified among healthy dogs examined in small animal clinics in Oslo. This research also included 49 clinical isolates of MRSP that were classified into 15 different MLST groups. The majority of isolates belonged to the ST258 and ST71 and they have been found in the same geographical area in Norway (Kjellman et al., 2015).

\section{RESISTANCE TO NON-BETA-LACTAM ANTIBIOTICS IN MRSP}

What should be pointed out is that the resistance phenotype to non-betalactam antibiotics is often related to their clonal group. For instance, the iso- 
lates from the most abundant clonal group CC71 were less resistant to amikacin, chloramphenicol, tetracycline and trimethoprim-sulfametoxasole while CC258 was less likely to be resistant to amikacin, enrofloxacin, gentamycin and chloramphenicol (dos Santos et al., 2016). In a research from Norway, it was shown that the clonal lineage ST71 was more resistant to antibiotics than other clonal groups. The highest resistance rates in ST71 included ciprofloxacin and gentamicin antibiotics as well (Kjellman et al., 2015). The clone ST496 is susceptible only to florfenicol and fusidic acid (Bergot et al., 2018). According to a study carried out in Finland, MRSP was more often multidrug-resistant than MSSP. The only exception is fusidic acid, to which both strains showed similar levels of resistance (around 24\%). Additionally, a total number of 219 MRSP isolates (100\%) were susceptible to amikacin (Grönthal et al., 2017).

In a research from Kasai et al. it was determined (2016) that therapy with minocycline was effective in the case of MRSP infection with SCCmec type III strains. It was found that the number of isolates belonging to the type $\mathrm{V}$ strains was susceptible to amoxicillin-clavulanic acid, cephalexin and cefazolin even if they were mecA positive, and in most cases, multidrug-resistant. SCCmec type III strains were more frequently resistant to oxacillin compared to type V isolates. In a research work conducted in Germany, it was established that MRSP isolates with high MIC to oxacillin were also frequently resistant to non-betalactam antibiotics such as erythromycin and other macrolides, clindamycin, tetracycline, enrofloxacin, sulfamethoxazole/trimethoprim (Nienhoff et al., 2011). In Poland, a total of 51 S. pseudintermedius isolates from the veterinary clinic and breeding kennels, mostly from dogs with pyoderma and bitches with reproductive disorders, were susceptible to vancomycin, daptomycin and linezolid. More than 50\% isolates were resistant to penicillin, tetracycline and macrolides. Resistance to ciprofloxacin was detected in $31.4 \%$ isolates (Ruzauskas et al., 2016). In a research work from Italy (Ventrella et al., 2017) resistance rates to sulfamethoxasole/trimethoprim, clindamycin, ciprofloxacin and doxycyline were much more pronounced in MRSP isolates than in MSSP. Almost all isolates (except one) were susceptible to gentamicin. MRSP isolates from dogs and cats that were treated at a veterinary clinic in Iran, when resistant to oxacillin/ cefoxitin, tend to develop additional resistance to gentamicin, tetracycline, lincomycin and erythromycin (Tabatabaei et al., 2019). MRSP isolates from two small clinics in Sydney showed increasing rates of resistance to fluoroquinolones, trimethoprim/sulfamethoxazole and erythromycin compared to MRSA isolates from the same clinic. It was concluded that the clonal lineage ST496 is the area of concern for public health since those isolates carry transferable genetic resistance determinants (Worthing et al., 2018). MRSP rarely causes health 
problems in cats, unlike in dogs. In a research work conducted by Kadlec et al. (2010) isolates were collected from European countries and North America and antimicrobial resistance data was compared. The data showed that the isolates from Canada were resistant only to $\beta$-lactam antibiotics and tetracycline, while isolates from Europe were also resistant to macrolide/lincosamide, gentamicin, kanamycin, trimethoprim and ciprofloxacin. The majority of isolates were also resistant to chloramphenicol and tetracycline.

\section{HUMANS AS MRSP HOSTS?}

Some methicillin-resistant Staphylococcus (MRS) clones are spreading worldwide and this is the main reason why much attention is devoted to decreasing MRS infection in human and veterinary medicine. Furthermore, human infections with $S$. pseudintermedius have been recorded sporadically (Stegmann et al., 2010). Dogs have been indicated as a natural reservoir of $S$. pseudintermedius since this species can be isolated from healthy animals as much as the ill ones. Hanselman et al. (2009) pointed out that household hygiene (i.e. hand washing) can be a crucial step in preventing human infection with bacteria originating from pets, providing less chance for bacteria to switch from their commensal to pathogenic state and become a threat, both to humans and animals. In their research, indistinguishable $S$. pseudintermedius isolates were found in 4/9 households in humans and their pets (dogs). In another study conducted during a dog show in Berlin, nasal swabs were taken from dogs and their owners and it was elucidated that six owners and 13 dogs carried S. pseudintermedius. In addition, one human isolate was MRSP. For a total of $21 \mathrm{~S}$. pseudintermedius isolates sequence type was defined and it was evident that isolates were heterogeneous and nine new sequence types were identified (Walther et al., 2012). On the other hand, in a research work in Sydney, conducted in two small veterinary clinics, MRSP was identified in $8 \%$ of personnel-owned dogs and $8 \%$ of veterinary personnel. Three MRSP isolates from personnel-owned dogs admitted to the clinic B were ST64 but the same ST was not identified in their owners. This finding implied that dogs got infected with $S$. pseudintermedius when being taken to clinic B but did not transfer it to their owners. Dogs with no visible skin lesions and generally regarded as healthy were included in the study. In these two clinics the most frequent MRSP isolate from dogs was ST469, but this clone was not identified in personnel-owned dogs, unlike ST64. Lack of human host tropism by MRSP was explained by a small sample size and the fact that dogs had to meet special selection criteria (Worthing et al., 2018). A research was conducted in 
a small animal hospital in Germany. It included swabs from employees and the hospital environment for isolation and characterization of Staphylococcus spp. isolates resistant to oxacillin. MRSP was detected in nasal swabs of two persons, from the hands of two persons and in three environmental swabs (floor in the waiting area, clippers in the emergency room and a table in the intensive care unit). Two spa types (t02 and t06) were identified among MRSP isolates. In addition, all isolates had related PFGE patterns, the same antibiotic resistance profiles and the same resistance genes indicating that the transfer of MRSP between dogs and humans had occurred (Feßler et al., 2018). Even though zoonotic transmission of $S$. pseudintermedius from dogs to humans is rarely documented, there are many pieces of evidence that such transmissions can happen. It was documented in a case report from Scotland that Clostridium perfringens and S. pseudintermedius were isolated from a patient with an ecthyma-like lesion in a forehead. This patient was also an owner of three Siberian husky dogs and therefore swabs from nostrils, mouth, ear, forelimb, hind limb axillae between toes and anal margin were taken from his pets. $S$. pseudintermedius was isolated from dog swabs but these isolates were not in concordance with isolates from the patient. Moreover, they were genetically unrelated which was confirmed by MLST. The human isolate was resistant to penicillin while isolates from dogs were susceptible. All isolates were susceptible to oxacillin (Robb et al., 2017). However, in a case study from Spain, $S$. pseudintermedius isolated from patients and dogs of the same household had identical PFGE patterns, sequence types and antimicrobial phenotype and genotype even if isolates were susceptible to methicillin (Lozano et al., 2017). Early studies, conducted in Denmark by Guardabassi et al. (2004), have shown that $S$. intermedius isolates from dogs and their owners show identical or close related PFGE patterns, but between households these isolates were genetically unrelated. It was not certain if these strains were transmitted from dogs to owners or vice versa. However, authors postulated that resistance genes can be transferred from S. intermedius to human S. aureus and, therefore, present a serious risk for human health. In a study conducted in the Netherlands, MRSP was found in 15/20 households in 18 dogs and six cats. In addition, MRSP was identified in 5/14 contact dogs and 4/13 contact cats in six households. Nasal swabs were taken from 45 humans who owned pets and only two swabs taken from the same household were MRSP positive. These owners had a cat with cystitis caused by MRSP. A total number of 141 personnel employed in the veterinary clinic ( 13 clinics were included in the study) agreed to participate in the second part of the study and only four persons had MRSP. Thirty-one (16\%) of environmental swabs was positive after the first sampling and after 
the usual hygiene protocol only $14 \%$ were still MRSP positive. The authors concluded that there is a small likelihood of humans being colonized by MRSP in contaminated household and hospital environments (Duijkeren et al., 2011). Scientists drew a comparison between MRSP isolates from dogs, veterinarians and dog owners in Thailand based on sequence types and the result has shown that ST45, 112, 169, 178, 181 and 183 are shared between them. A new cassette SCCmec $_{57395}$ was identified in isolates from dogs and veterinarians which belong to ST45. However, this cassette was not found in isolates from dog owners (Chanchaithong et al., 2014).

\section{CONCLUSION}

In conclusion, MRSP therapy is difficult to undergo since most of the isolates are multidrug-resistant and resistant to beta-lactam antibiotics. The data about successful antibiotic therapy is scarce. Local treatment with fusidic acid should be considered, where possible, including the use of non-antibiotic substances for local and surgical wound treatment. Albeit there is little information about the role of MRSP in human infections, the nosocomial transmission and widespread contamination of the environment is an existing threat. Therefore, it is important to prevent contact with infected animals and have personal hygiene. In that way, the spread of MRSP between animals and humans will be restricted and antibiotic therapy, which is assigned as critical in human medicine, avoided.

\section{ACKNOWLEDGMENT}

This work was supported by a grant from the Ministry of Education, Science and Technological Development of the Republic of Serbia, Grant number TR 31071.

\section{Authors' contributions}

Authors contributed equally to this manuscript.

\section{Competing interest}

Authors declared no conflict of interests regarding the present paper. 


\section{REFERENCES}

1. Bergot M., Martins-Simoes P., Kilian H., Châtre P., Worthing K.A., Norris J.M., Madec J.Y., Laurent F., Haenni M. Evolution of the population structure of Staphylococcus pseudintermedius in France. Frontiers in Microbiology, 9, 3055. doi: 10.3389/fmicb.2018.03055.

2. Chanchaithong P., Perreten V., Schwendener S., Tribuddharat C., Chongthaleong A., Niyomtham W., Prapasarakul N. 2014. Strain typing and antimicrobial susceptibility of methicillin-resistant coagulase-positive staphylococcal species in dogs and people associated with dogs in Thailand. Journal of Applied Microbiology, 117, 572-586.

3. Corro M., Skarin J., Börjesson S., Rota A. 2018. Occurrence and characterization of methicillin-resistant Staphylococcus pseudintermedius in successive parturitions of bitches and their puppies in two kennels in Italy. BMC Veterinary Research, 14, 308, https://doi.org/10.1186/s12917-018-1612-z.

4. van Duijkeren E., Kamphuis M., van der Mije I.C., Laarhoven L.M., Duim B., Wagenaar J.A., Houwers D.J. 2011. Transmission of methicillin-resistant Staphylococcus pseudintermedius between infected dogs and cats and contact pets, humans and the environment in households and veterinary clinics. Veterinary Microbiology, 150, 338-343.

5. Feßler A.T., Schuenemann R., Kadlec K., Hensel V., Brombach J., Murugaiyan J., Oechtering G., Burgener I.A. Schwarz S. 2018. Methicillin-resistant Staphylococcus aureus (MRSA) and methicillin-resistant Staphylococcuspseudintermedius (MRSP) among employees and in the environment of a small animal hospital. Veterinary Microbiology, 221, 153-158.

6. Gordon R.J., Lowy F.D. 2008. Pathogenesis of methicillin-resistant Staphylococcus aureus infection. Clinical Infectious Diseases, 46(Suppl 5), S350-S359.

7. Grönthal T., Eklund M., Thomson K., Piiparinen H., Sironen T., Rantala M. 2017. Antimicrobial resistance in Staphylococcus pseudintermedius and the molecular epidemiology of methicillin-resistant S. pseudintermedius in small animals in Finland. Journal of Antimicrobial Chemotherapy, 72, 1021-1030.

8. Guardabassi L., Loeber M.E., Jacobson A. 2004. Transmission of multiple antimicrobial-resistant Staphylococcus intermedius between dogs affected by deep pyoderma and their owners. Veterinary Microbiology, 98, 23-27.

9. Hanselman B.A., Kruth S.A., Rousseau J., Weese J.S. 2009. Coagulase positive staphylococcal colonization of humans and their household pets. Canadian Journal of Veterinary Medicine, 50, 954-958. 
10. Kadlec K., Schwarz S., Perreten V., Andersson G.U., Finn M., Greko C., Moodley A., Kania S.A., Frank L.A., Bemis DA., Franco A., Iurescia M., Battisti A., Duim B., Wagenaar J.A., van Duijkeren E., Weese J.S., Fitzgerald J.R., Rossano A., Guardabassi L. 2010. Molecular analysis of methicillin resistant Staphylococcus pseudintermedius of feline origin from different European countries and North America. Journal of Antimicrobial Chemotherapy, 65, 1826-1837.

11. Kadlec K., Wei $\beta$ S., Wendlandt S., Schwarz S., Tonpitak W. 2016. Characterization of canine and feline methicillin-resistant Staphylococcus pseudintermedius (MRSP) from Thailand. Veterinary Microbiology, 194, 93-97.

12. Kasai T., Saegusa S., Shirai M., Murakami M., Kato Y. 2016. New categories designated as healthcare-associated and community-associated methicillin-resistant Staphylococcus pseudintermedius in dogs. Microbiology and Immunology, 60, 540-551.

13. Kjellman E.E., Slettemeås J.S., Small H., Sunde M. 2015. Methicillin-resistant Staphylococcus pseudintermedius (MRSP) from healthy dogs in Norway-occurrence, genotypes and comparison to clinical MRSP. Microbiology Open, 4, 857-866.

14. Lozano C., Rezusta A., Ferrer I, Pérez-Laguna V., Zarazaga M., Ruiz-Ripa L., Revillo M.J., Torres C. 2017. Staphylococcus pseudintermedius human infection cases in Spain: Dog-to-human transmission. Vector Borne Zoonotic Diseases, 17, 268-270.

15. Moodley A., Riley M.C., Kania S.A., Guardabassi L. 2013. Genome sequence of Staphylococcus pseudintermedius strain E140, an ST71 Europeanassociated methicillin-resistant isolate. Genome Announcements, 1, 2, e00207-12.

16. Nienhoff U., Kadlec K., Chaberny I.F., Verspohl J., Gerlach G.F., Kreienbrock L., Schwarz S., Simon D., Nolte I. 2011. Methicillin-resistant Staphylococcus pseudintermedius among dogs admitted to a small animal hospital. Veterinary Microbiology, 150, 191-197.

17. Nisa S., Bercker C., Midwinter A.C., Bruce I., Graham C.F., Venter P., Bell A., French N.P., Benschop J., Bailey K.M., Wilkinson D.A. 2019 Combining MALDI-TOF and genomics in the study of methicillin resistant and multidrug resistant Staphylococcus pseudintermedius in New Zealand. Scientific Reports, 9:1271, https://doi.org/10.1038/s41598-018-37503-9.

18. Perreten V., Kadlec K., Schwarz S., Andersson G.U., Finn M., Greko C., Moodley A., Kania S.A., Frank L.A, Bemis DA., Franco A., Iurescia M., Battisti A., Duim B., Wagenaar J.A., van Duijkeren E., Weese J.S., Fitzgerald J.R., Rossano A., Guardabassi L. 2010. Clonal spread of methicillin-re- 
sistant Staphylococcus pseudintermedius in Europe and North America: an international multicentre study. Journal of Antimicrobial Chemotherapy, $65,1145-1154$.

19. Robb A.R., Wright E.D., Foster A.M.E., Walker R., Malone C. 2017. Skin infection caused by a novel strain of Staphylococcus pseudintermedius in a Siberian husky dog owner. Journal of Medical Microbiology, 4, doi 10.1099/jmmcr.0.005087.

20. Ruzauskas M., Couto N., Pavilonis A., Klimiene I., Siugzdiniene R., Virgailis M., Vaskeviciute L., Anskiene L., Pomba C. 2016. Characterization of Staphylococcus pseudintermedius isolated from diseased dogs in Lithuania. Polish Journal of Veterinary Science, 19, 7-14.

21. Dos Santos T.P., Damborg P., Moodley A., Guardabassi L. 2016 Systematic review on global epidemiology of methicillin-resistant Staphylococcus pseudintermedius: Inference of population structure from multilocus sequence typing data. Frontiers in Microbiology, 7:1599. doi: 10.3389/fmicb.2016.01599.

22. Sasaki T., Kikuchi K., Tanaka Y., Takahashi N., Kamata S., Hiramatsu K. 2007. Reclassification of phenotypically identified Staphylococcus intermedius strains. Journal of Clinical Microbiology, 45, 2770-2778.

23. Sasaki T., Tsubakishita S., Tanaka Y., Sakusabe A., Ohtsuka M., Hirotaki S., Kawakami T., Fukata T., Hiramatsu K. 2010. Multiplex-PCR method for species identification of coagulase-positive Staphylococci. Journal of Clinical Microbiology, 48, 765-769.

24. Sewid A.H., Hassan M.N., Ammar A.M., Bemis D.A., Kania S.A. 2018 Identification, cloning and characterization of Staphylococcus pseudintermedius coagulase. Infection and Immunity, 86:e00027-18. https://doi. org/10.1128/IAI.00027-18.

25. Somayaji R., Priyantha M.A.R., Rubin J.E., Church D. 2016. Human infection due to Staphylococcus pseudintermedius, an emerging zoonosis of canine origin: report of 24 cases. Diagnostic Microbiology and Infectious Disease, 85, 471-476.

26. Stegmann R., Burnens A., Maranta C.A., Perreten V. 2010. Human infection associated with methicillin-resistant Staphylococcus pseudintermedius ST71. Journal of Antimicrobial Chemotherapy, 65, 2047-2048.

27. Tabatabaei S., Najafifar A., Badouei A.M., Salehi Z.T., Tamai A.I., Khaksar E., Abbassi M.S., Ghazisaeedi F. 2019. Genetic characterization of methicillinj-resistant Staphylococcus aureus and Staphylococcus pseudintermedi$u s$ in pets and veterinary personnel in Iran: new insights into emerging methicillin-resistant S. pseudintermedius (MRSP). Journal of Global Antimicrobial Resistance, 16, 6-10. 
28. Velhner M., Kozoderovic G., Suvajdzic Lj., Todorovic D., Petrovic J. 2016. Genetic mechanisms of methicillin resistance in Staphylococcus aureus (MRSA) and its capacity of transmission: a brief review. Arhiv Veterinarske Medicine, 9, 29-37.

29. Ventrella G., Moodley A., Grandolfo E., Parisis A., Corrente M., Buonavoglia D., Guardabassi L. 2017. Frequency, antimicrobial susceptibility and clonal distribution of methicillin-resistant Staphylococcus pseudintermedius in canine clinical samples submitted to a veterinary diagnostic laboratory in Italy: a 3-year retrospective investigation. Veterinary Microbiology, 211, 103-106.

30. Walther B., Hermes J., Cuny C., Wieler L.H., Vincze S., Elnaga Y.A., Stamm I., Kopp P.A., Kohn B., Witte W., Jansen A., Conraths F.J., Semmler T., Eckmanns T., Lübke-Becker A. 2012 Sharing more than friendship-nasal colonization with coagulase-positive Staphylococci (CPS) and co-habitation aspects of dogs and their owners. PLoS ONE, 7(4): e35197. doi:10.1371/ journal.pone.0035197.

31. Worthing K.A., Brown J., Gerber L., Trott D.J., Abraham S., Norris J.M. 2018. Methicillin-resistant staphylococci amongst veterinary personel, personnel-owned pets, patients and the hospital environment of two small animal veterinary hospitals. Veterinary Microbiology, 223, 79-85.

Submitted: 02.09.2019.

Accepted: 15.11.2019. 